\title{
PHILOLOGY
}

\section{ПОРАДА ЯК СУГЕСТИВНИЙ СКЛАДНИК УКРАЇНСЬКОГО МЕТЕОДИСКУРСУ}

\author{
Кулібаба М. О., старший викладач \\ Украйна, Одеса, Одеська державна академія будівниџтва та архітектури
}

DOI: https://doi.org/10.31435/rsglobal_ws/28022020/6939

\section{ARTICLE INFO \\ Received: 11 December 2019 \\ Accepted: 10 February 2020 \\ Published: 28 February 2020 \\ KEYWORDS \\ advice, \\ meteorological discourse, \\ pragmatic variants, \\ marker, \\ prompting, \\ functional style.}

\begin{abstract}
The aim of this study is to elucidate the pragmatic and language specificity of advice as a suggestive component of Ukrainian meteorological discourse. The weather forecasts published on air of the radio station Kraina FM by Natalka Didenko were the observation material. The subject of the study is the communicative-pragmatic parameters of autumn and winter advice of the weather forecaster.

Advice in meteorological discourse is implemented in several pragmatic variants: recommendation, warning, prohibition, proposal and appeal. Every type is aimed at preserving life and health of the population, rational organization of work, everyday routine and rest, consolidation of the population with regard to national and universal human values. Within the limits of advice professional and "non-professional" advice are distinguished, which implemented professional and "nonprofessional" intentions of the weather forecaster. Serious and humorous advice of a proactive nature has been noticed.

Means of expression are imperatives, indicatives, modal and negative constructions. There is an integration of publicistic, scientific, colloquial and belles-letters styles in the meteorological advice that provide its necessary suggestiveness.
\end{abstract}

Citation: Кулібаба М. О. (2020) Porada yak Suhestyvnyi Skladnyk Ukrainskoho Meteodyskursu. World Science. 2(54), Vol.2. doi: 10.31435/rsglobal_ws/28022020/6939

Copyright: () 2020 Кулібаба М. О. This is an open-access article distributed under the terms of the Creative Commons Attribution License (CC BY). The use, distribution or reproduction in other forums is permitted, provided the original author(s) or licensor are credited and that the original publication in this journal is cited, in accordance with accepted academic practice. No use, distribution or reproduction is permitted which does not comply with these terms.

Вступ. Пораду як мовленнєвий жанр, комунікативну тактику або інтенцію студіюють А. Архипенко, Л. Бондаренко, Н. Депутатова, О. Наумук, О. Петрова, А. Романченко, А. Соловйова, Т. Шеловських, С. Шабат-Савка, О. Шутова та ін. Зокрема С. Шабат-Савка, аналізуючи комунікативну інтенцію спонукання, зауважує, що вона відбиває волевиявлення мовця, різне за інтенсивністю, й охоплює як категоричну, так і некатегоричну форму спонукання (ШабатСавка 2012, с. 153). До першої форми зараховано наказ, що кваліфіковано як імперативні висловлення, до другої - прохання, пропозицію, пораду тощо, тобто інші бажані для суб'єкта мовлення комунікативні акти, реалізація яких узалежнена від волі адресата (Каранська 1992, с. 24). А. Романченко досліджує пораду як одну 3 комунікативних тактик хеджувальної стратегії. Розглядаючи специфіку жанру лінгвістичної рецензії, мовознавиця стверджує, що «суть поради рецензента полягає в його намірі висловити адресатові рекомендацію виконати певну дію з метою найбільш оптимальної реалізації авторських інтенцій» (Романченко 2017, с. 310-311). Порада, на іiі думку, має нейтральну тональність,, що зумовлено особливостями наукового дискурсу, де й реалізується стратегія хеджування за допомогою тактики поради (Романченко 2019, с. 403). О. Шутова вбачає іллокутивну мету поради в намірі спонукати адресата сприйняти іï та вчинити відповідну дію. Втім, рішення щодо ії виконання залишається за тим, на кого спрямовано пораду - 
за адресатом. Дослідниця переконана в сугестивному характері поради, оскільки експліцитно чи імпліцитно в ній висловлено певну настанову, рекомендацію чи побажання (Шутова 2019, с. 130). Водночас зауважимо, що порада належить до тих жанрів, що характеризується необлігаторністю виконання, можливістю виконувати певні дії на розсуд адресата. Разом 3 тим із кута зору адресанта порада зорієнтована на корисність із боку адресата.

Метою пропонованого дослідження $€$ з'ясування семантичної, прагматичної та синтаксичної специфіки поради як сугестивного складника українського метеорологічного дискурсу. Матеріалом спостереження послугували прогнози погоди, оприлюднені в ефірі радіостанції Країни FM авторкою-синоптикинею Наталкою Діденко. Предметом вивчення $\epsilon$ мовні та прагматичні аспекти поради, що охоплюють осінь - зиму 2019 року.

Результати. Семантичний спектр поради доволі широкий, оскільки він містить категоричні й некатегоричні іiї варіанти: рекомендація, попередження, застереження, вимога, погроза, заборона, консультація, пропозиція, побажання тощо. Тлумачний словник сучасної української мови подає таке трактування поради: пропозиція, вказівка, як діяти в яких-небудь обставинах, допомога добрим словом у скруті; рада (Великий тлумачний словник 2005, с. 244). Мовознавці кваліфікують пораду як повідомлення про те, що для адресата, на якого його скеровано, буде оптимальним та корисним (Шутова 2019, с. 130). А. Романченко вирізняє два типи порад: із відтінком рекомендації та $з$ відтінком побажання (Романченко 2019, с. 403), кожна з яких втілюється завдяки певним мовним одиницям і залежить від інтенції автора.

Порада $є$ комунікативним актом, активно вживаним в українському метеорологічному дискурсі. ІЇ̈ формулюють за допомогою кількох продуктивних синтаксичних конструкцій. До їхнього складу входять мовні одиниці, що слугують маркерами, які акцентують увагу слухачів / читачів і спонукають їх скористатися порадами фахівця.

За семантикою висловлювання вирізняються дві групи комунікативних актів, в яких утілено пораду: порада фахівця і порада громадянина. Фахова порада стосується власне погодних умов та передбачає рекомендацію одягатися відповідно до прогнозованих синоптичних обставин, а також застереження чи категоричну заборону на певні вчинки та поведінку й має на меті вплинути на дії адресатів, що убезпечать від негативних наслідків негоди, Поради, скеровані на оптимізацію фізіологічного стану людини за певної погоди завдяки правильному підібраному одягу, головному убору та взуттю, як правило, висловлено у формі наказового способу, напр.: ... холодно, тому одяг на тиждень плануйте відповідний, $а$ особливо неслизьке взуття; Одягайтесь обов 'язково тепліше, особливо надвечір, бо так звана температура комфорту буде на 2-5 градусів нижчою за реальну. Своєрідною підказкою обрати відповідний одяг і взуття слугують висловлювання, де міститься певна вказівка, якими саме повинні бути предмети одягу: куртка, шапка, шалик, термобілизна, рукавички, джинси, черевики, чобітки тощо, напр.: ... самі у пошуках подарунків та покупок обов 'язково одягніть щось із каптуром. Бо нести ще й парасолю в руках буде незручно.

Рідше порада висловлена за допомогою модальних слів варто або треба: 3-го грудня в Украӥні очікується сніг та мокрий сніг, на дорогах - казна-що, тобто, ожеледиия та малопрохідні тротуари. Тому пішоходам варто подбати про відповідне взуття, а водіям - про словник ненормативної лексики; 3 п'ятнищі в Україні почне холоднішати, з 31 грудня 2019 року -1 січня 2020 року - знову теплішати. Тому в ией період треба встигнути вигуляти зимовий одяг.. Поради, наведені вище, потрактовуємо як рекомендацію синоптика, що збереже здоров’я людини.

Можливі варіанти утеплення, на думку синоптика, охоплюють назви різних фасонів та матеріалу, особливо це стосується верхнього одягу й головних уборів: Тому $i$ сьогодні ввечерi, $i$ завтра дуже, дуже тепло одягайтеся, обов 'язково щиось пухове, вільне, вітронепродувне, на шию вовняний шалик у мінімум два оберти, щось з каптуром, під джинси термобілизну або щось за 100 ден, рукавички, шапки і товстішу підошву; Вітер завіватиме з південного заходу, 5-12 м/с, тобто, трохи поривчастий, для прогулянок обов язково закутайте шию шаликом. Ну, й - шапки, тим більше, що зараз вибору варіантів - море. Шапки, вушанки, кепки, з баламбонами, люрексом, цитатами і брендами, каптури, хустки, труби, $і$ щее, й іще. За потепління рекомендовано демісезонний одяг, напр.: Так щзо на кілька днів закиньте товсті куртки й шапки, до нас з короткочасним дружнім візитом завітає весна.

Мовними індикаторами в таких висловлюваннях слугують дієслова одягатися, закутатися, насунути, захищатися. Для привертання уваги залучено прислівники обов'язково, 
дуже, дуже-дуже тепло, тепліше, щуільніше, напр.: А поки щзо не перемерзайте, підступний перехідний період так $і$ чекає, щуоб наслати віруси та застуди, захищайтеся шапками, теплими котами, термобілизною та відповідними черевиками й чобітьми; I насуньте шапку щиільніше на вуха, щзоб не здуло.

Нерідко порада фахівця скерована на орієнтування українців щодо швидкості руху пішоходів й автомобілістів, способу їхнього пересування, напр.: На дорогах з'явиться ожеледиия, пересовуйтесь повільніше; I не забувайте про тумани, вмикайте фари, будьте обережними, любіть ближнього свого $і$ за сусіднім кермом, $і$ на тротуарі; Шановні водії! Віддайте належне цим прекрасним осіннім метеорологічним явищам своєю увагою, обережністю та увімкненими фарами.

Фахова порада часто стосується місця, яке потрібно обирати як пішоходам, так і водіям, напр.: Паркуйте розумно автомобілі, не лізьте високо на дах, не стійте з подружкою, яку випадково зустріли, довго під старим гіллястим деревом, краще зайдіть у найближчу кав 'ярню; Вітер південно-східного напрямку досягатиме 15-22 м/с, тобто, ймовірні итормові пориви. Дуже уважно обирайте місие для парковки автомобіля, враховуючи часом ненадійність білбордів (i за формою та й деколи за змістом). Дієслівними маркерами аналізованих висловлювань слугують лексеми обходьте, не затримуйтесь, не стійте, а іменниковими маркерами - місце, дерево, білборд. Розглянуті висловлювання витлумачуємо як поради фахівця, скеровані на запобігання нещасним випадкам та смерті громадян. Найчастіше порада-рекомендація виражається імперативами у формі 3 особи множини або лексемами варто, треба, що містять семи настійності й теж маніфестують рекомендацію (Романченко 2019, с. 406).

Доволі активною є дієслівна форма із заперечною часткою, що категоризує пораду й тим самим реалізує пораду-заборону, напр.: I, між іниим, де опади та низька температура повітря, там і ожеледиця. Водії, щуо їуть на Заході України, і не думайте без зимової гуми подорожувати, може бути небезпечно; Тому не затримуйтесь довго під деревами, особливо великими та гіллястими, білбордами, дуже уважно обирайте місче парковки автомобіля, візьміть цее особливо до уваги, хто займається будівництвом - чи крупним, коли може виникати небезпека під час роботи баштових кранів, чи скромне перекриття даху сарайчика; Вітер південно-західний, веселий, весняний, до сильного. Не затримуйтеся з подружкою під старим гіллястим деревом, підіть краше у найближче кафе.

Середню активність вираження поради мають висловлювання, маркерами яких виступають лексеми можна та краще, що репрезентують пораду-пропозицію, напр.: Надалі в Україні переважатиме тепла волога погода, а похолодання очікується з 27-28 грудня. Можливі навіть сніг та 'мінуси', і одразу ожеледиця. Тому поки щзо можна побігати по сухому, не спотикаючись, за святковими подарунками; Але, може, це $i$ добре, бо в нас $і$ так навколо надто багато турборежимів та прискорень. Краще поступово, природно та з розумом, щзоб не злетіти. Наведені висловлювання забезпечують реалізацію поради з відтінком пропозиції: Адже смог вже пішов, тепло ще тут, листопад відволікся на якісь інші, не хмарно-холодні справи - якраз можна подихати і набратися оптимізму на іншу, похмурішу, осінь; У Києві 31 грудня вранці та в першу половину дня - без істотних опадів, далі, у вівторок, почнеться мокрий сніг, місиями з дощем. Тому, якщзо щзе залишилися якісь справи, щзось докупити, $з$ кимось зустрітися, то краще тридиять першого грудня вранці чи у першу половину дня.

Метеопорада може мати узагальнений характер й активізувати увагу громадянина в осінньо-зимовий період, коли погодні умови часто ускладнюються. Уваги та обережності потребують, на думку синоптика, штормовий вітер (Бо опадів хоча й не очікується, а ось вітер якраз розгуляється - будьте обережними при итормових південно-східних поривах; Поривчастий, до сильного, вітер ще залишиться у більшості областей. Обережно!; Східний вітер почне розганятися до штормових поривів - обережно!), дощ, сніговий покрив, хуртовина (Там, де температура повітря перевищуватиме нуль, сніг переходитиме у дощ. На дорогах будьте уважнним особливо; Дощі пройдуть у західних областях, де вони можуть бути сильними, а в Карпатах - з мокрим снігом та навіть хуртовинами, туристи - обережно!), ожеледиця ( $А$ ије означає, щзо дороги можуть бути з ожеледицею чи просто дуже слизькими від першої листопадової камі. Обережно!), туман (Дощуі малоймовірні, проте з туманів може випадати мряка. Видимість на дорогах обмежена, уважнн!). Такий різновид поради витлумачуємо як пораду-застереження, деонтична модальність якої є пріоритетною. Порада-застереження слугує 
своєрідним приписом, що заохочує людину до конкретних дій, зокрема до особливої активізації зору, або накладає певні заборони на певні дії, зокрема щодо швидкості транспортних засобів.

Привертання уваги до складних погодних умов відбувається завдяки мовним маркерам, що спонукають мешканців України до відповідної поведінки: будьте обережними, обережно, уважно, особлива увага, напр.: Враховуючи, що від такої погоди ми відвикли, i, очікуючи невелике зниження температури повітря, будьте максимально обережними на вулиці, на дорогах та тротуарах; Двадиять першого листопада рвоне сильний вітер, обережнно!; Видимість у туманах погіршуватиметься до 300-500 метрів, уважнн!; Де сніг, мокрий сніг - там і ускладнення ситуаиіі на дорогах, ожеледиия, 'каша' на дорогах та тротуарах. Водії! Особлива увага! Ступінь сугестивного впливу адресанта на адресата значною мірою пов'язаний з особистістю сугестора (Шутова 2019, с. 130), бо ефективність впливу узалежнена від соціальної значущості адресантасиноптика, від його авторитетності та вміння чітко сформулювати пораду, від ступеня володіння необхідною інформацією, від обізнаності в певній сфері діяльності й довіри до фахівця.

Якщо синоптик $є$ відомою особистістю, публічною людиною й активним громадянином, то він може скористатися можливістю, щоб дати й інші, санітарно-оздоровчі, культурно-освітницькі, екологічні й навіть побутові поради населенню, які не мають жодного стосунку до прогнозування погоди: Підготуйте гарну музику в машину або аудіокнижку, щоб гармонізувати простір автосалону; Довитрушуйте килими, подописуйте листи, купіть святкову листівку в книгарні $С$, подзвоніть на далекі села чи скайпом друзям у далекі країни... Такі поради мають відтінок пропозиції.

У межах «загальнолюдської» поради - поради другого різновиду - також можна виокремити поради-заборони (Надалі буде ще тепліше. Картоплю садити не біжіть, насіння не скуповуйте, все ж зима ще буде), поради-нагадування (Не забудьте через кілька годин, о 4 ранку, переставити час на годину назад!), поради-заклики (Бережіть себе $\boldsymbol{i}$ довіряйте в усьому лите професіоналам, а не тріскучим невігласам. Їхній час - завжди позаду, хоч як би комусь не здавалося інакше; Працюйте, відпочивайте лише на здоров я та задоволення; Вітряна погода потребуватиме закутуватися. Не дайте вірусам жодного шансу; На Заході є ймовірність сильних дощів, у Карпатах - мокрий сніг та хуртовини. Шановні туристи! Не завдавайте зайвого клопоту службам порятунку та собі нервів).

Поради публічної людини скеровані на підтримання загальнолюдських (Не пускайте свойх старших у магазин чи поліклініку одних, супроводжуйте ї...; Поки ще є трохи часу перед Новим роком, подзвоніть комусь далекому і самотньому, привітайте стареньких сусідів, бо насправді вони потребують радості від подарунків та уваги часом більше, ніж діти. Купіть ӥм зефір, пухкий тортик, зробіть парові котлетки, м'які булочки, норвезький оселедець, хурму, щяось таке, щоб легко було жувати, і обов'язково свіже й смачненьке, щоб ми нікого не забули посеред яскравого передсвяткового буму), культурних та моральних цінностей (День зимового сонщестояння приходить до нас завтра. Незважаючи на похмуру погоду з невеликими дощами, туманами та мрякою, можна починати розучувати нові або згадувати старі веснянки, бо Сонце почне статечно повертати на літо; Поки дозволяє погода, поганяйте, хоч би й в обід, по виставках та фільмах, чи просто у найближчому скверику походіть колами), на виховання екокультури (Лишіть у лісі хоча б трохи грибів для їжачків та горіхів для білочок. А свої кульки із сміттям не забудьте забрати з собою), на збереження здоров'я (За можливості, тримайтеся ближче до водойм - до річок чи ставків, ідеально бути коло моря, бо сухе листя, яке наакумулювало всі шкідливі викиди за літо й половину осені, не дає нормально дихати), раціональну організацію побуту й дозвілля (Одягайтеся тепліше, перевірте, чи закручені з минулого року батареї, щоб надто близько не знайомитися із сусідами, захистіть чи врятуйте хризантеми, пришийте нарешті тудзик на тепле пальто словом, готуємося до щорічної переправи на зимові свята; Читайте книжки, пийте смачні чаї, ходіть по свіжому повітрю $і$ в усіх ситуачіях рахуйте до десяти; I нам не варто хаотично працювати та відпочивати - все спокійно і без надлишку емоцій).

3 огляду на викладене вище зазначимо, що прагматичні параметри поради як складника українського метеодискурсу передбачають опозицію щодо ії інституційності / неінституційності. У першому випадку йдеться про фахову пораду синоптика, у другому - пораду медійної особистості.

За емоційним забарвленням поради в метеодискурсі поділяються на ті, що мають нейтральний характер (3 вітром не жартуйте, обходьте старі гіллясті дерева, паркуйте з розумом автомобіль), і ті, що позначені гумористичними нотками (Хто вже звик до комарів та 
мух, відпустіть їх у вирій; Тому котам поки щзо зауваження робити не варто, у них - березневий настрій, хай нявкають; Не переплутайте сезони і не починайте часом садити картоплю чи шукати розпродажі пуховиків; Дош очікується 23 грудня не лише в Києві, але про ие - пізніше. Тому можна покласти під подушку великим діткам парасолю, скоро знадобиться; Якщо вам здавалося, ще атмосфера не притримується свойх законів, то ось ией сніг та похолодання перед Новим роком показують, що треба нам хреститися, якщо здається; Вітер може бути сильним, тому шапка з шаликом і щось важке у сумиі, наприклад, нова красива керамічна миска, не будуть зайвими). У багатьох випадках, коли авторка прогнозу погоди дає гумористичну пораду, то й на своїй сторінці у фейсбуці використовує дужку, що вказує на посмішку.

Зазвичай пораді безпосередньо передує причина або вона називається після поради, коли вказують на атмосферні явища чи опади, напр.: У Києві у середу пройде дощ, вдень буде близько +7 градусів. 27-28 грудня готуйтеся ловити сніжинки на носа та тепліше одягайтеся; На дорогах проростає ожеледиця, оберіть неслизьке взуття. Нерідко синоптик у підрядному реченні аргументує пораду, вживаючи сполучники із семантикою причини або мети: Там, де падатиме інтенсивніший мокрий сніг - Захід, Вінниччина, Житомирщина - може бути налипання мокрого снігу, тому не паркуйте автомобілі під старими великими деревами; Так що тримайте голову в рівновазі, бо такі метаморфози синоптичні можуть трохи нас гальмувати.

Як непряму пораду, висловлену синоптиком, потрактовуємо випадки, де використано неспецифічну форму іiі вираження. У такому разі синтаксична конструкція не містить дієслівімперативів. Натомість дієслівні форми вжито в дійсному способі, але в значенні наказового, рідко - в неозначеній формі. Наведемо приклади: Це потепління буде короткочасним, 1-2 грудня знову до нас прийде похолодання. Тому поки що однаково уважно стежимо за прогнозами погоди та за головою. бо мінливість й стрибки будуть і там, і там; ... розпочинаємо новий тиждень новою синоптичною ситуацією, одужанням, хто захворів, піклуванням про здоров`я усім решті, припинити сваритися у соимережах і жити свойм життям, а не чужим;). Прямі та непрямі поради розрізняють залежно від ступеня категоричності й експліцитності (Нерян 2020, с. 12). У досліджуваному дискурсі непрямі поради - це ті, що не є директивами, не виражені імперативами й імпліцитно звернені до адресатів.

Частина таких висловлювань виконує функцію консолідації фахівця з громадянами, які слухають прогнози погоди по радіо, напр.: А поки що радісно махаємо рукою вредному ретроградному Меркурію... ; А поки що тепліше одягаємося та відганяємо шапками із баламбонами віруси та застуди. Можемо припустити, що більшість подібних висловлювань містить і певного роду автогенну пораду, під якою розуміємо пораду, зорієнтовану на себе, напр.: Елегантні пальта та черевики на тоненькій підошві пакуємо на "далекі села", у дальні кутки шаф; Тому поки що Новий рік просто плануємо, а погоді дякуємо, що така вона в нас зараз комфортна, як на листопад. Зауважимо, що ці нібито автогенні поради значною мірою скеровано на населення, на спонукання його до здорового способу життя, до віри в себе, до вияву кращих рис українців.

Отже, мовне оформлення поради характеризується кількома моментами. Воно стосується семантичного аспекту поради щодо бажаного - небажаного, особистого громадського, фізичного - ментального, синтаксичної специфіки стосовно відповідного вибору імперативних, індикативних чи модальних висловлень. Також важливим є спосіб вираження спонукання: прямий або непрямий, експліцитний чи імпліцитний, від чого залежить ступінь сугестивності тієї чи тієї поради.

Нерідко в пораді спостерігаємо різні стилістичні засоби, що увиразнюють або іiі серйозність, або гумористичність, зокрема епітети, метафори, антитези, ампліфікацію, асиндетон тощо, напр.: Тому поки носимо світлі речі, красиво закидаємо шалик за спину, темні окуляри, переходимо дорогу виключно в дозволених місиях, дякуємо один одному навіть за дрібнииі, нарешті робимо плановий медичний огляд, не п ємо дешевого, абиякого вина, фрукти й овочі любимо не лише за смак, а й за фантастичні кольори, словом, иінуємо теплі дні жовтня за красу, тепло $і$ за прийдешні спогади сльотавим листопадом.

Л. І. Шевченко вказує, що в медіажанрі поради можуть інтегровано вживатся засоби публіцистичного стилю й елементи інших стилів (Шевченко 2011). Досліджуваний фактичний матеріал теж широко ілюструє комбінацію кількох функційних стилів, зокрема публіцистичного викладу інформації з елементами наукового стилю. Доказом такого симбіозу слугує використана лексика безпосередньо зі сфери метеорології (південно-східний вітер, налипання мокрого снігу, 
ускладнення погоди, обмежена видимість тощо): У західних областях у п ятниию можливий сильний південно-східний вітер, обережно з капелюхами; Відповідно, на дорогах ситуація може бути складною, слизькою та, через щільні хмари, із поганою видимістю, особливо ввечері. Водї, не поспімайте ганяти за новорічними подарунками і не тримати дистанцію.

Найбільшою мірою в пораді залучено елементи розмовно-побутового стилю, що зумовлено форматом спілкування - невимушеною розмовою синоптика зі слухачем, напр.: Подихайте нормальним киснем на природі, якщуо буде можливість, накостиляйте по дорозі тим, хто палить листя, і швиденько тікайте; Тому використайте п ятницю для підищщення хвостів, а вихідними із спокійною совістю можна валятися під пледом; Суха погода з невеликим морозом вночі та 'плюсами' вдень - практично ідеальна груднева ситуачія, шчоб тимчасово відволіктися від бурчання на `не таку погоду $i$ зайнятися чимось конструктивним; ... відпочиньте сьогодні ввечері вдома $і$ плюньте нарешті на те олів $є$., де натрапляємо на розмовну й просторічну лексику, фразеологічні одиниці розмовного характеру (плювати на щзось, підчищати хвости).

Наскрізною особливістю поради в метеодискурсі Наталки Діденко $є$ синтез публіцистичного та художнього стилів, що забезпечує прогнозу погоди в цілому та пораді як його складнику велику емоційно-експресивну насиченість, засвідчує творчу індивідуальність авторки, їі світобачення, напр.: А поки щуо чекаємо на зимовий дебют $i$ стежимо уважно за свіжими прогнозами погоди; Протиставимо холоду та сірим хмарам веселі, з різнокольорових ниток, баламбони на шапках, строкаті хустки й шалики, смішні яскраві шкарпетки, розумний, відповідно погоді, одяг, екоторби із карикатурами на дурість $i$ пихатість, консультації виключно з лікарями, а не з сусідками по фейсбуку, словом, все робимо, щзб показати прийдешній холодній та хмарній погоді, щцо ми й не таких бачили. Саме завдяки дуже поширеним елементам художнього стилю фахова й «нефахова» порада стають неодмінним стимулом дослухатися до пропонованого, втілити його в життя.

Висновки. Порада в метеорологічному дискурсі реалізується в кількох прагматичних варіантах. Її діапазон охоплює рекомендацію, застереження, заборону, пропозицію, заклик. Кожен різновид поради забезпечує намагання синоптика залучити різні аспекти, що гарантують збереження життя й здоров’я населення, уможливлюють раціональну організацію праці, побуту й відпочинку, консолідують громадян стосовно підтримання національних і загальнолюдських цінностей. Отож, у межах поради виокремлено фахову й «нефахову» пораду. Завдяки першому різновиду реалізовано професійні інтенції синоптика, а завдяки другому - громадянську позицію, втілену за допомогою інших комунікативних інтенцій. Обидва різновиди можуть бути як серйозними, так і гумористичними, але обов'язково ініціативними, оскільки синоптик дає поради не на прохання адресата, а за власною ініціативою.

Типовими засобами вираження поради $\epsilon$ імперативи, модальні слова, заперечні конструкції. Допоміжними одиницями, що сприяють висловленню поради, слугує вживання індикатива в ролі імператива та інфінітивів.

У пораді, що функціонує в медійному просторі в межах метеодискурсу, спостерігається інтеграція публіцистичного стилю 3 науковим, розмовно-побутовим і художнім стилями, що відповідно демонструють використовувані мовні одиниці, передусім на лексико-семантичному рівні.

\section{ЛIТЕРАТУРА}

1. Великий тлумачний словник сучасної української мови / уклад. і голов. ред. В. Т. Бусел (2005). Київ - Ірпінь.

2. Каранська М. У. (1992). Синтаксис сучасної української літературної мови : навч. посіб. Київ : НМК ВО.

3. Нерян С. О. (2020). Аргументативний дискурс української інтернет-комунікації в соцмережах: лінгвопрагматичний аспект : автореф. дис. ... канд. філол. наук : 10.02.01. Одеса.

4. Романченко А. П. (2019) Елітарна мовна особистість у просторі наукового дискурсу: комунікативні аспекти: монографія. Одеса : Одеський національний університет імені I. I. Мечникова.

5. Романченко А. (2017). Комунікативні тактики стратегії хеджування. Наукові записки. Серія: Філологічні науки. Кропивницький. Вип. 153: 310-314.

6. Шабат-Савка С. Т. (2014). Категорія комунікативної інтенції в українській мові : монографія. Чернівці: Букрек.

7. Шевченко Л. И. (2011). Стиль как средство реализации авторского замысла в жанре «Совет». Теория $u$ технология иноязычного образования : материалы V междунар. науч.-практ. конф. Вып. 6 (Сер. 9): $27-31$.

8. Шутова О. А. (2019). Совет как суггестивный речевой жанр поучающего дискурса. Известия ВГПУ. Филологические науки. № \% (138): 129-134. 